\title{
Mineralogical characterization of pre-hispanic pottery at the Mesa de Los Santos region, Colombia
}

\author{
Karina Andrea Portilla-Mendoza1, Diego Armando Pinzón-Núñez ${ }^{1}$, Leonardo Moreno-González ${ }^{2}$, \\ Ricardo Mier-Umaña ${ }^{1}$, Carlos Alberto Ríos-Reyes ${ }^{1 *}$, Jose Antonio Henao-Martínez ${ }^{3}$
}

DOI: http://dx.doi.org/10.18273/revbol.v41n2-2019007 @ @

Forma de citar: Portilla-Mendoza, K.A., Pinzón-Núñez, D.A., Moreno-González, L., Mier-Umaña, R., RíosReyes, C.A., and Henao-Martínez, J.A. (2019). Mineralogical characterization of pre-hispanic pottery at the Mesa de Los Santos region, Colombia. Boletín de Geología, 41(2), 123-136. DOI: 10.18273/revbol.v41n22019007

\begin{abstract}
The application of mineralogy in archeology has been growing in interest in particular in relation to establishing the origin of the clays used in the elaboration of ancient ceramic artifacts. The mineralogy did not show a clear relationship with the colors expressed by the pottery system defined by the archaeologists; that is, independent of the color of the slip, each group has the same mineralogical components. Fourteen Pre-Hispanic pottery sherds from the Mesa de Los Santos region (Colombia) were selected for mineralogical characterization by X-ray diffraction, scanning electron microscopy and Fourier transform infrared spectroscopy. The objective of the work was to contribute to the knowledge of the production technology and elucidate a possible regional origin of these ceramics. The observed mineralogical phases were plagiocalse, quartz, potassium fledspar, clay minerals, micas, carbonate minerals, and iron oxides. Firing temperatures are in the ranges $600-800^{\circ} \mathrm{C}$ for almost all the analyzed samples.
\end{abstract}

Keywords: Pottery; sherds; mineralogy; firing temperatures; Mesa de Los Santos region.

\section{Caracterización mineralógica de la cerámica prehispánica de la región de La Mesa de Los Santos, Colombia}

\begin{abstract}
RESUMEN
La aplicación de la mineralogía en arqueología ha venido creciendo en interés en particular con relación a establecer la procedencia de las arcillas utilizadas en la elaboración de artefactos cerámicos antiguos. La mineralogía no mostró una relación clara con los colores expresados por el sistema cerámico definidos por los arqueólogos; es decir, independiente del color del engobe, cada grupo tiene los mismos componentes mineralógicos. Se seleccionaron catorce piezas de alfarería prehispánica de la región de la Mesa de Los Santos (Colombia) para la caracterización mineralógica por difracción de rayos X, microscopía electrónica de barrido y espectroscopia infrarroja de transformada de Fourier. El objetivo del trabajo fue contribuir al conocimiento de la tecnología de producción y dilucidar una posible procedencia regional de estas cerámicas. Las fases mineralógicas observadas fueron plagioclasa, cuarzo, feldespato potásico, minerales de arcilla, micas, minerales de carbonato y óxidos de hierro. Las temperaturas de cocción están en los rangos $600-800^{\circ} \mathrm{C}$ para casi todas las muestras analizadas.
\end{abstract}

Palabras clave: Piezas; cerámicas; mineralogía; temperaturas de cocción; región de la Mesa de Los Santos.

\footnotetext{
1 Escuela de Geología, Universidad Industrial de Santander, Bucaramanga, Colombia. (*) carios@uis.edu.co, kandreitapomen@gmail.com, pinuardi@hotmail.com, rimier@uis.edu.co

${ }^{2}$ Escuela de Historia, Universidad Industrial de Santander, Bucaramanga, Colombia. lmoreno@uis.edu.co

${ }^{3}$ Escuela de Química, Universidad Industrial de Santander, Bucaramanga, Colombia. jahenao@uis.edu.co
} 


\section{INTRODUCTION}

Several analytical techniques, such as X-ray fluorescence spectroscopy, X-ray diffraction, scanning electron microscopy, electron microprobe analysis, infrared and Raman spectroscopy, high-resolution $\mathrm{X}$-ray microtomography and gas chromatographymass spectroscopy have been used in the mineralogical characterization of pottery sherds (e.g., Bong et al., 2010; Kahl and Ramminger, 2012; Grifa et al., 2013; Damjanović et al., 2014; Tarquini et al., 2014; Lettieri, 2015; Noll and Heimann, 2016). However, the selection of the suitable analysis methods should be based on the type, form and amount of samples to be analyzed (Lettieri, 2015). Archaeological analysis of preHispanic ceramic technology and its socio-economic, cultural and historical scope, contrasted with data from geosciences, in addition to its documentation value (e.g., Belfiore et al., 2007; Barrios-Neira et al., 2009; Iordanidis et al., 2009) allows qualifying archaeological inferences based on the understanding of the attributes of the raw materials used for the manufacture of ceramic artifacts (e.g., Kramar et al., 2012; Moroni and Conti, 2006; Ravisankar et al., 2014) and the technology involved in the manufacturing process (e.g., Schwedt and Mommsen, 2004; Mangone et al., 2009; Belfiore et al., 2010), which may reveal significant information about the provenance of the raw materials with which the ceramic artifacts were manufactured (e.g., Sherriff et al., 2002; Barone et al., 2005). The presence or absence of certain mineral phases provides information regarding the firing conditions in terms of both temperature and atmosphere used during pottery production (Iordanidis et al., 2009). The aim of this work was to carry out the mineralogical characterization of archaeological pre-Hispanic pottery sherds from the Mesa de Los Santos region, Colombia (FIGURE 1), representing the beginning of a long-term research developing provenance studies based on the archeometry of ceramic pottery, which will provide new interesting and useful information on pre-Hispanic societies.
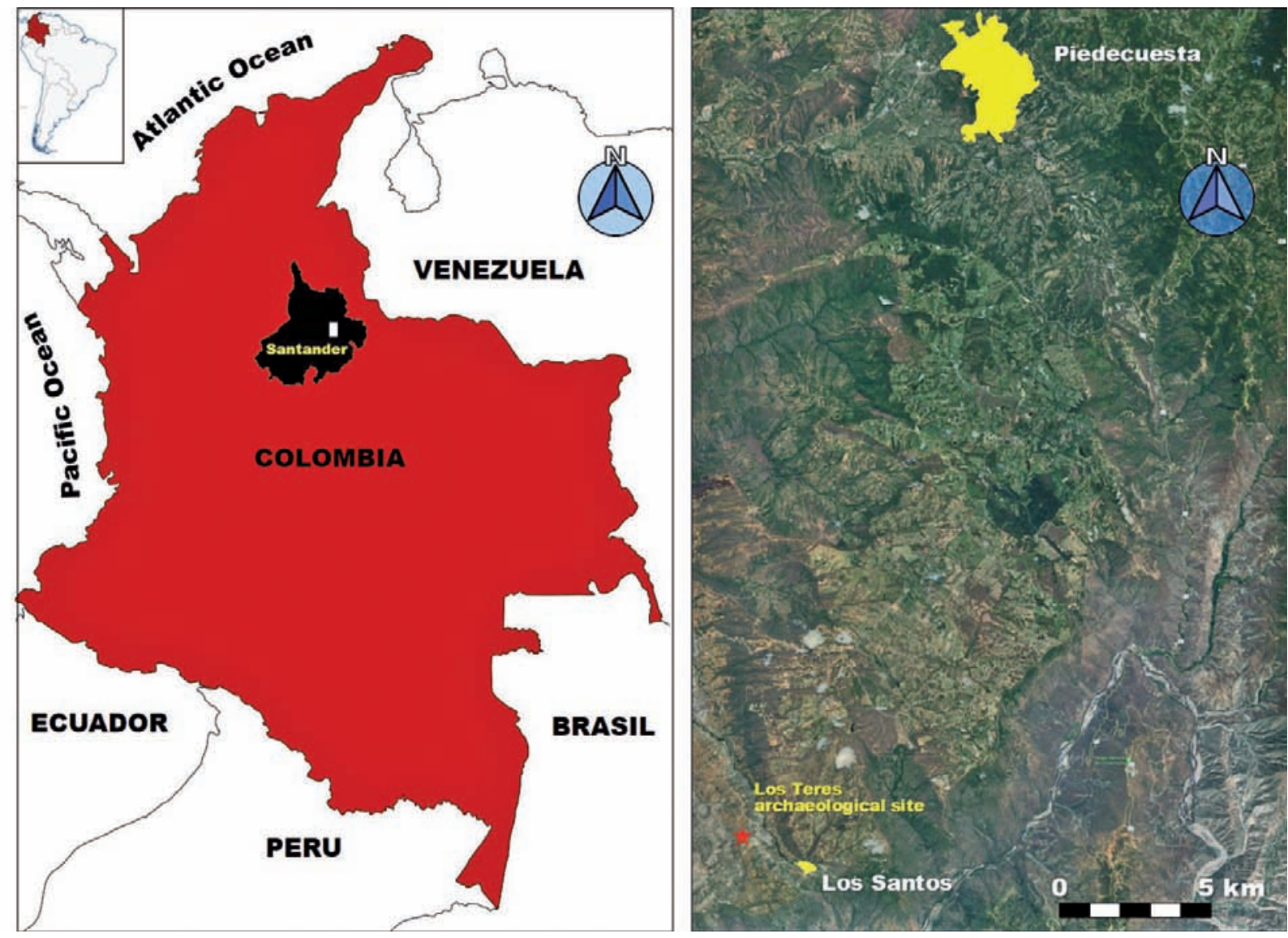

FIGURE 1. Geographical location of Los Teres archaeological site indicated by the red star. Adapted and modified from Google Earth. 


\section{ARCHAEOLOGICAL ASPECTS}

The Guane pre-Hispanic society, between the eleventh century and the arrival of the Spanish conquerors (sixteenth century) occupied the mountainous area of the Department of Santander, Eastern Cordillera of the Colombian Andes. Its social development, reached the level of chiefdom society, characterized by social complexity and stratified social organization, its responses to irrigation ditches and channels for agricultural production, its fluid trade with other ethnic groups such as Muisca, Chitareos and Yareguies and with its form of autonomous government in each zone and, only a centralized government in case of external aggression, according to the sources of sixteenthcentury chroniclers. The social organization and form of government of this ancient culture had contents of social differentiation and in the political leadership it was expressed in the autonomy of each territory governed by a local cacique, which allowed an integration and control of the territories (small regional autonomies), under the influence of a local commercial network for the supply of basic consumer goods and interregional trade to obtain sumptuous goods for the groups of power, as recorded in the sources of sixteenthcentury chroniclers. The material expressions of the Guane society are varied: small towns, cemeteries in hills and caves that were formed by the calcareous geology of the region and that in the big canyons left holes where the most prestigious people were buried and, that in some cases several of them were subjected to mummification and ritual complexes, whose relatives crossed the difficult topography, the access by the cornice of deep precipices and the rich funeral trousseau that accompanies the deceased, including the ceramic vessels and whose contained foods, symbolically express the step to another life. Among the evidence of Guane material culture, the pottery stands out for the presence of muscovite mica, the diversity of forms (globular pots with handles, bowls, glasses, large bottles etc.) and, for the use of painting as a decorative technique (polychromy) and the decoration with complex geometric designs (especially in glasses) and lines painted on the body in most of the ceramic vessels. This type of ceramic and decorative variety has been found in the most superficial layers of archaeological excavations; and, on the contrary, in the deeper horizons its abundance is smaller, at the same time, that new forms appear (plates, bowls with bases and in some cases with handles) and decorative techniques (incised, pressed or modeled) in the strata deeper. It is precisely this variety in the pottery, what has generated this study of ceramics within the pre-Guane - Guane archaeological regional contenxt, considering that it can be about the technological continuity of the same human group or that it can correspond to two agricultural societies, different potters.

\section{SAMPLES AND ANALYTICAL METHODS}

Fourteen samples (pottery sherds) from the excavation site were selected for this study, taking into account that sampling represented the diversity observed macroscopically among pottery fabric, surface and decoration and is proportional to the number of pottery sherds identified in each category of the ceramic system of classification proposed by Moreno-González (2012). Samples were taken from original objects and then prepared for analysis, taking care not to include pottery sherds of the painted surfaces because this approach was not focused on the characterization of pigments. Pottery sherds were characterized through conventional petrography and X-ray powder diffraction (XRPD) and scanning electron microscopy (SEM). $\mathrm{X}$-ray diffractograms were recorded in a XRPD using a BRUKER D8 ADVANCE X-ray diffractometer equipped with Da Vinci geometry and equipped, operating at $40 \mathrm{kV}$ and $30 \mathrm{~mA}$ with $\mathrm{Cu}-\mathrm{K} \alpha 1$ radiation: $\lambda=1.5406 \AA$ in the $2 \theta$ range of $3.5-70^{\circ}$. Microtexture and chemical composition of pottery sherds were examined using the back-scattered electron (BSE) imaging on a FEI QUANTA 650 FEG-ESEM, under the following analytical conditions: magnification = 100-20000x, WD = 9.0-11.0 mm, HV $=20 \mathrm{kV}$, signal $=\mathrm{BSE}$ in ZCONT mode, detector = BSED, EDS Detector EDAX APOLO X with resolution of 126.1 $\mathrm{eV}$ (in. $\mathrm{Mn} \mathrm{K} \alpha$ ). Structural characterization from the functional groups by FTIR-ATR, using a computer model THERMO SCIENTIFIC IS50, with diamond crystal in the spectral range $400-4000 \mathrm{~cm}^{-1}$.

\section{RESULTS AND DISCUSSION}

\section{Petrography}

FIGURE 2 illustrates the analyzed pottery sherds from the pre-Hispanic Los Teres archaeological site, which were selected for this study basing on the principle of representativeness in which an attempt was made to cover the diversity of colors and pottery fabrics observed in the entire ceramic system. The observation of pottery sherds allowed identifying 5 main ceramic groups: red, gray, black, brown and redish brown groups (TABLE 1). A preliminary visual inspection 
of the pottery surfaces was performed through a stereomicroscopy to distinguish the residues from the pottery material and optimize the sampling of the asreceived pottery sherds. The observation of pottery sherds under the stereomicroscope, allowed identifying 5 main ceramic groups: red, gray, black, brown and redish brown groups. Red group includes the A2-1 (orange-AC), F2-2 (intense-AC), A3-4 (matte-AC), D2-11 (orange-AC without mica), and B2-2 (intenseAC without mica) subgroups. Gray group includes the D4-4 (dark gray-AC), B5-6 (dark gray-CE without mica), F3-3 (light gray-AC), and E5-4 (light grayAC without mica) subgroups. Black group includes the B4-6 (black-AC), and A2-4 (black-AC without mica) subgroups. Brown group includes the C3-3 (brown-AC) subgroup. Redish brown group includes
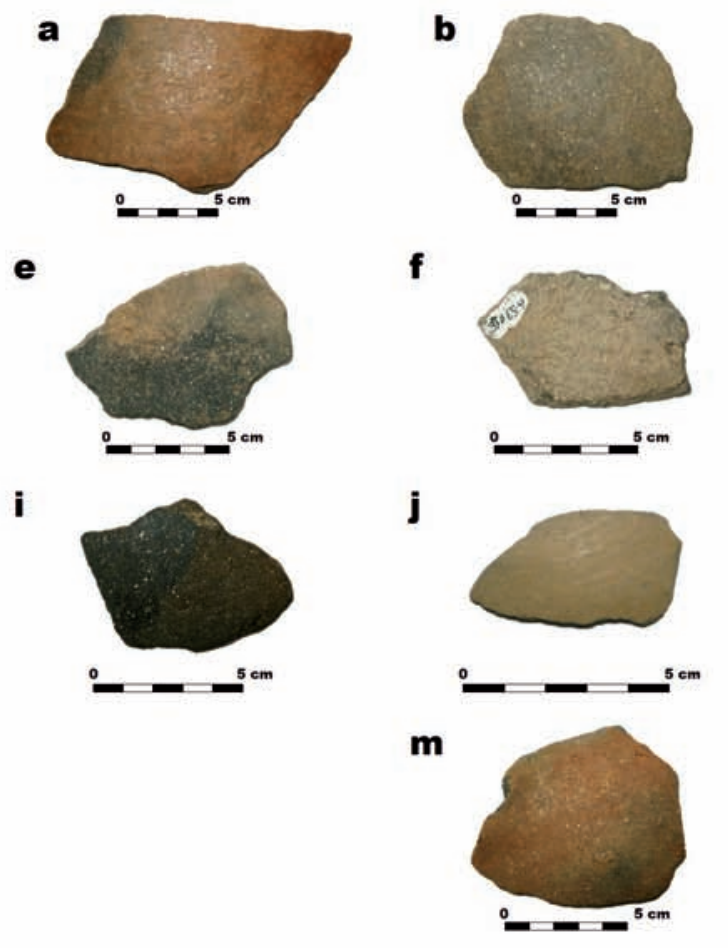

the D2-6 (redish brown-AC) subgroup. All subgroups with its subtypes with external, internal color or both. The classification of these ceramic groups was based on visual characteristics such as the external and internal color, surface treatment such as engobe or the absence of this, polishing, content, size and density in the structure of the paste of the degreaser and finding of a high amount of visible muscovite in the pottery sherd. Nonetheless, the mineralogy and composition of the paste weren't considered. To approach the compositional and mineralogy differences in the pottery sherds, the set of samples were taken from each one of the ceramic groups being each sample representative from each group and each sample were taken from original objects and then prepared for analysis, taking care not to include fragments of the painted surfaces.

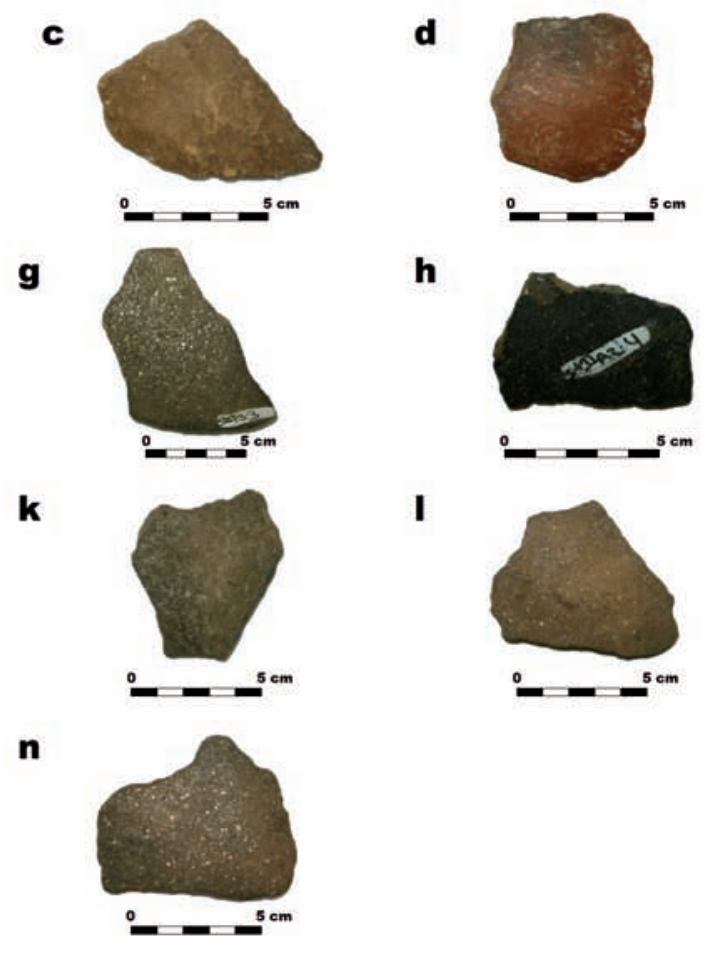

FIGURE 2. Samples of pottery sherds from the pre-Hispanic Los Teres archaeological site: (A)-(D) red, (F)-(G) gray, (H)-(I) black, (J)-(M) brown and $(\mathrm{N})$ reddish brown groups.

The use of petrographic analysis has been increasing in the study of archaeological ceramics. FIGURE 3 illustrates the main petrographic features of the analyzed pottery sherds. In general, they show an opaque and pseudo-isotropic microcrystalline and heterogeneous clayed matrix with frequent to common voids, which tend to show a subparallel orientation. It is brown to reddish-brown in PPL and black to dark brown in XPL. Inclusions reveal that grains are poorly sorted. The coarse fraction is mainly composed of monocrystalline or polycrystalline quartz, plagioclase, micas (biotite and muscovite), amphibole, pyroxene, calcite, and opaque minerals lithoclasts of metamorphic rocks (quartzite, micaschist, biotite-amphibole or amphibolitic gneiss), with rare potassium feldspar. The fine fraction shows predominant to frequent opaque 
minerals, monocrystalline quartz, common micas (biotite and muscovite), scarce plagioclase, potassium feldspar and amphibole. In general, one of the main characteristics for these pottery sherds is the presence of high amount of muscovite flakes. The textural pattern can be either preferentially oriented or showing a random orientation of muscovite. It must be specified that the presence of muscovite is a natural product, taking into account that in some pottery artifact it was intentionally added and, therefore, archaeologists who have worked in this region consider that it is an addition for decorative purposes. There is not evidence of the presence of high temperature anorthite, and, therefore, it was probably hidden in the amorphous phases. Most of the amorphous phases observed in the matrix were created after firing at a high temperature enough to dehydrate and dehydroxylate the clay minerals present in the raw clayed paste with which the ceramic artifacts were manufactured. Albite can occur, which is a reflection of the stability of the mineral under changing firing temperatures, which may indicate that the raw clayed paste with which the ceramic artifacts were manufactured were exposed to high temperatures. Alkaline feldspars present in the pottery sherds probably proceed from the raw clayed plaste with which the ceramic artifacts were manufactured. However, they also can react to firing conditions, with the formation of polymorphs of high temperature. Carbonate minerals occur minly in samples of the red, black, brown and redish brown groups are absent in samples of the gray group. There an evident transformation of the raw clayed paste with which the ceramic artifacts were manufactured, which is accompanied by the dehydration and dehydroxylation of clay minerals and the formation of non-crystalline amorphous phases. Similarly, after cooking of the raw clayed paste for the manufacture of ceramic artifacts, some clay minerals can be rehydroxylized and reconstruted.

TABLE 1. Results of quantitative analysis by XRDP, showing the percentage of pottery's crystalline and amorphous phases. NC represents that the crystalline phase was identified; however, due to its low percentage it is not possible to do its quantification.

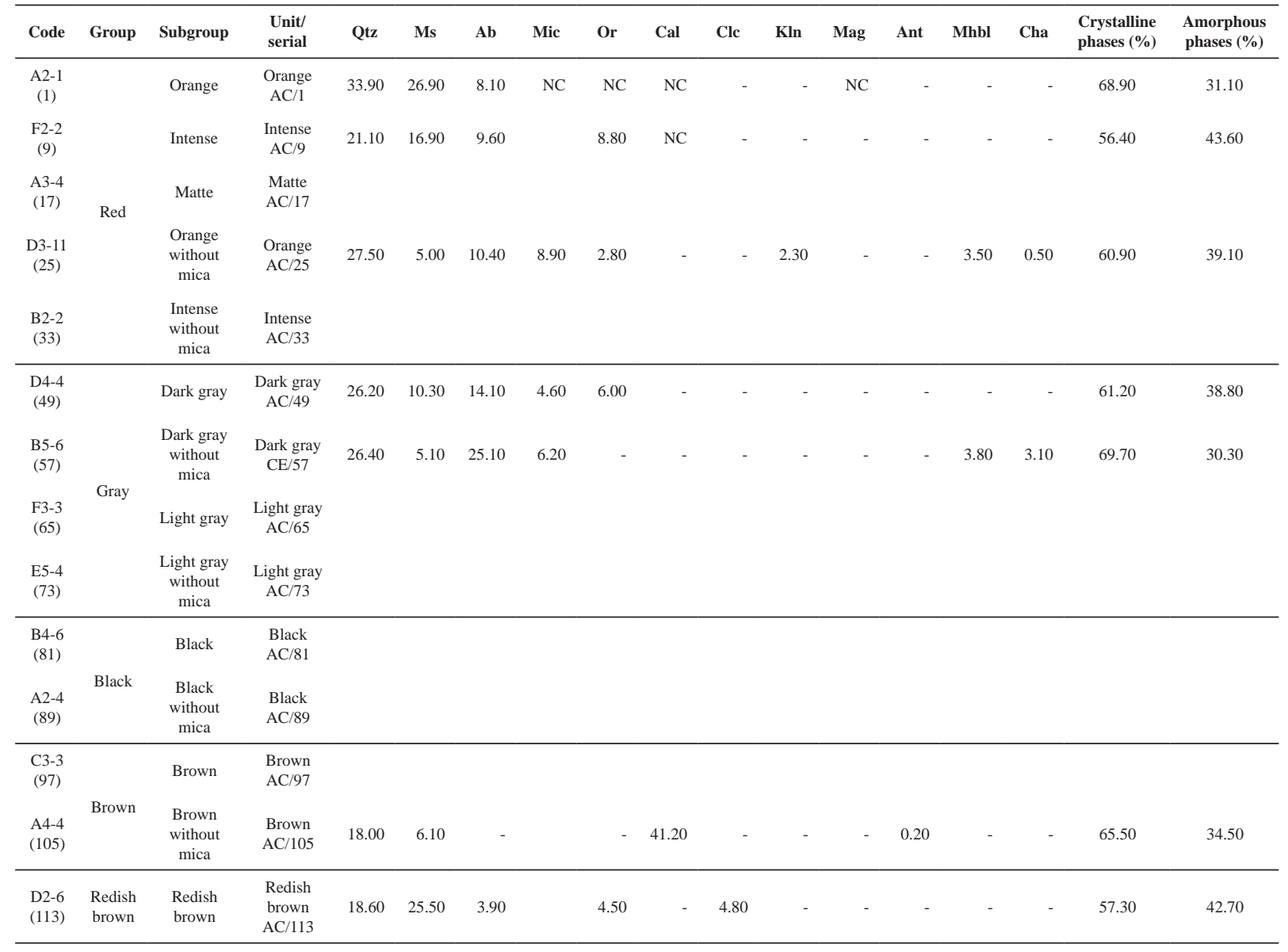



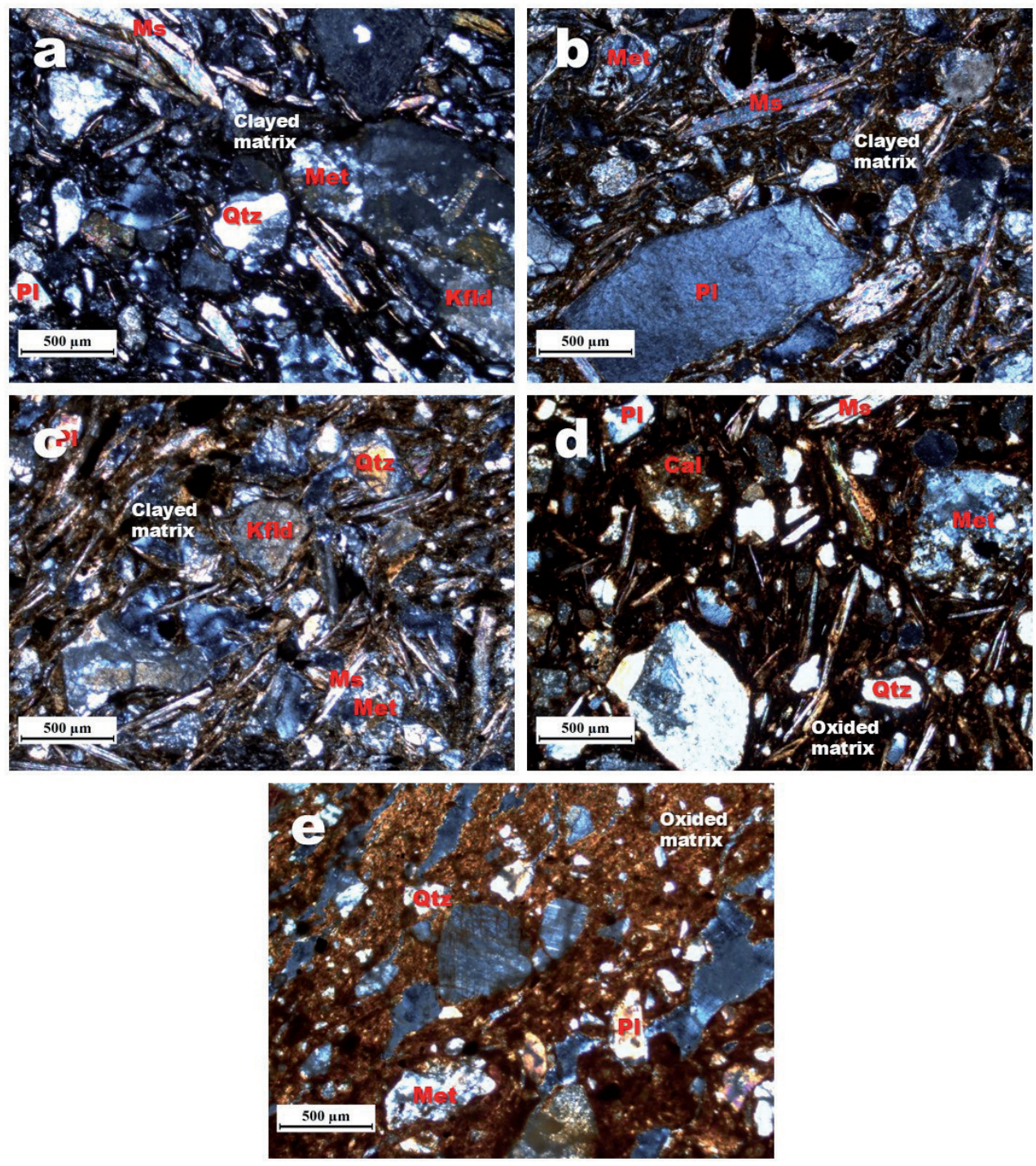

FIGURE 3. Microphotographs of thin sections of the analyzed pottery sherds of the A. red, B. gray, C. black, D. brown and E. reddish brown groups (polarized light, crossed polarizators, scale bar $=500 \mu \mathrm{m}$. Met, clast of metamorphic rock.

\section{X-ray powder diffraction}

XRPD analysis reveal that the observed mineralogical phases were albite, quartz, microcline, orthoclase, sanidine and plagioclase, clay minerals, micas, carbonate minerals, and iron oxides. Mineral abbreviations are after Whitney and Evans (2010). Traces of hematite can cause a vivid orange colour of the pottery sherds, which implies an oxidizing firing atmosphere, whereas samples do not contain hematite suggest a low firing temperature (Kramar et al., 2012). The presence of magnetite revels that it was formed under reducing conditions (Sciau, 2016). TABLE 1 shows the mineral composition of the pottery sherds analyzed by XRPD. FIGURE 4 illustrates the corresponding XRPD patterns. Results indicate that the pottery sherds are mainly composed of quartz, muscovite, albite and orthoclase/ microcline (except sample A4-4 (105), which contains abundant calcite), with minor Mg-hornblende, diopside, gehlenite, chabazite, anatase, clinochlore and kaolinite, and traces of magnetite/hematite. Data reveals that: 1) the crystalline phases range from 56.40 to $69.70 \%$ and the amorphous phases range from 30.30 to $43.60 \%$ and 2 ) the scarce occurrence of clay minerals (kaolinite) in the analyzed pottery sherds. 


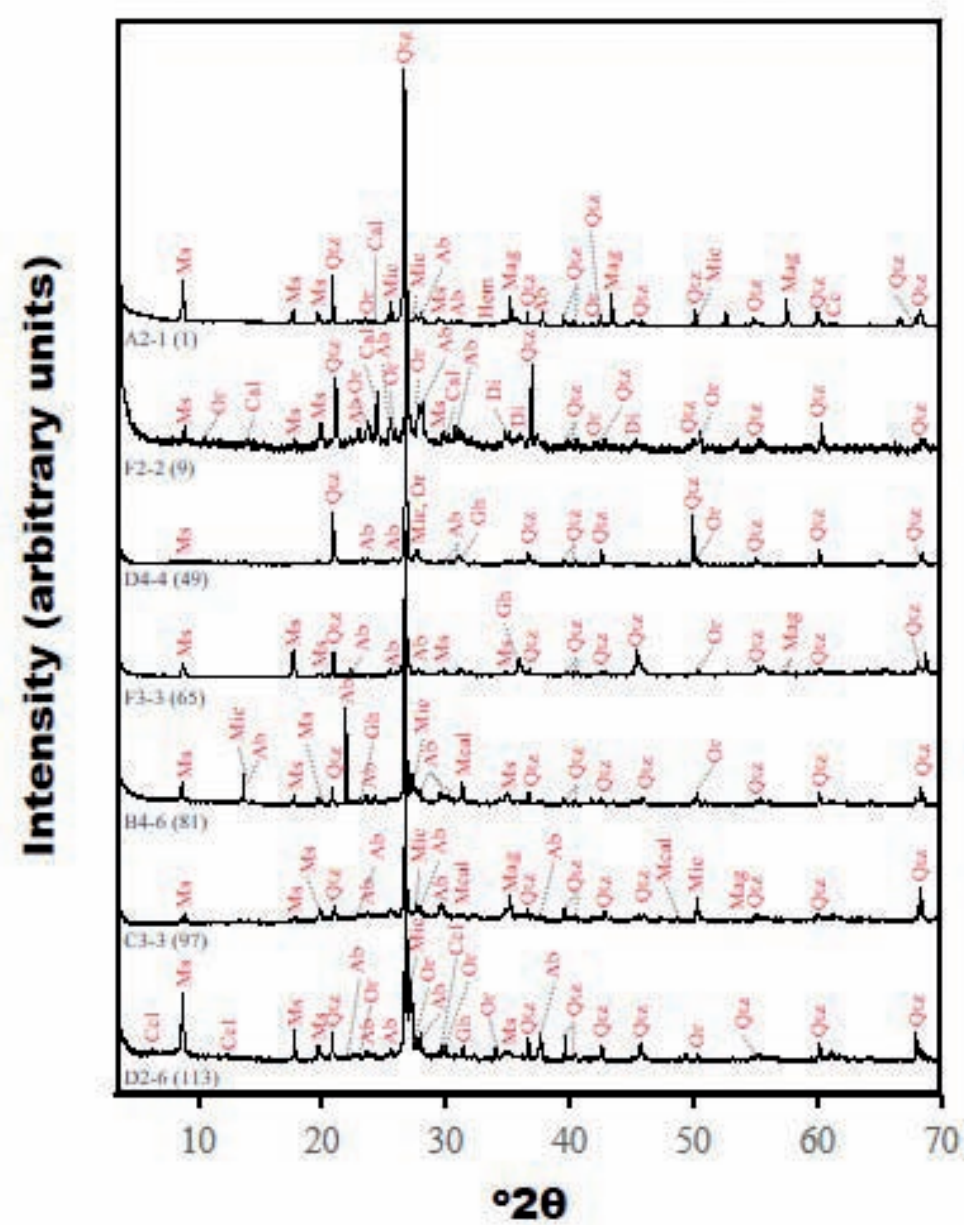

FIGURE 4. XRPD patterns of pottery sherds obtained by quantitative analyses.

\section{Scanning electron microscopy}

SEM analyses of the pottery sherds provided information about their microstructure and mineral morphology (FIGURE 5) developed during the firing of the raw materials used in their manufacture, which is very useful to estimate the firing temperature of the analyzed pottery sherds based on the characterization of their morphology and degree of vitrification as suggested by Tite et al. (1982). The degree of particle interconnection is important because it suggests an increase in the firing temperature. Maniatis and Tite (1978, 1981) defined, based on the fusion textures observed in SEM images, four degrees of vitrification (no vitrification; initial vitrification; vitrification; total vitrification) according to the temperature reached. No vitrification was mainly evidenced as a mortar texture. There are pottery sherds that show some light buckles and occasional rounded edges of the small clay plates, which suggest that although the pottery artifact did not reach a state of vitrification, some minerals reacted at the firing temperature. Faced with this challenge it is decided to accept the degree of initial vitrification which do not have clearly interconnected filaments, but if they have a marked structural anisotropy. The vitrification is observed in most of the analyzed pottery sherds as vitrified filaments mostly connected to each other forming networks with the same orientation despite the amount of inclusions of amorphous matter, clay minerals and scarce pores. The total vitrification was evident in some pottery sherds, especially observed with the texture "bubbly", which is attributed to partial fusion in high temperatures $\left(850^{\circ} \mathrm{C}\right)$, particularly in non-carbonated ceramics (Maniatis and Tite, 1981). Taking into account that pores (from 5 to $100 \mu \mathrm{m}$ ) are isolated (FIGURE 5), they indicate that the total vitrification did not reach its final state. The development of the glassy phase which implies high temperatures, is in agreement with the indicators 
of firing temperature or neoformation of minerals, suggesting that in the manufacture of the ancient ceramic artifacts the Guane potters paid more attention to control the degree of cooking of the vessel and thus prevent it from fracturing and preventing fulfill a previously determined function, where the temperature control played an important role to achieve the result as an archaeological product.
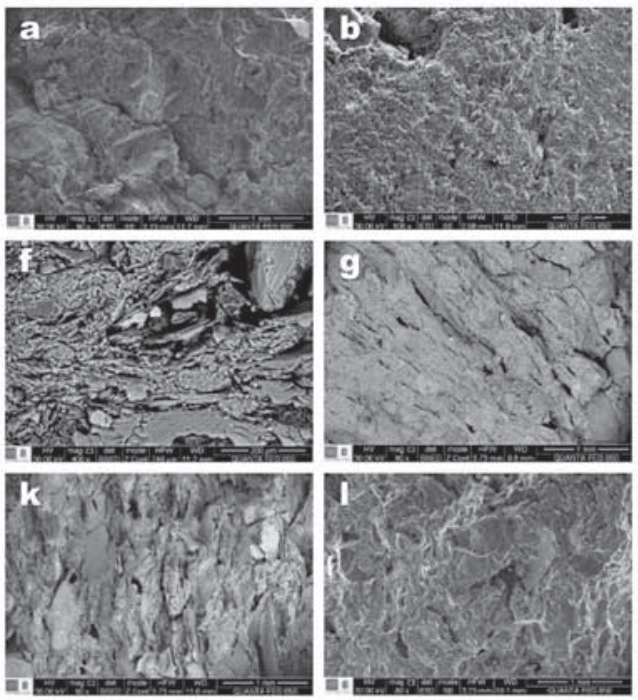
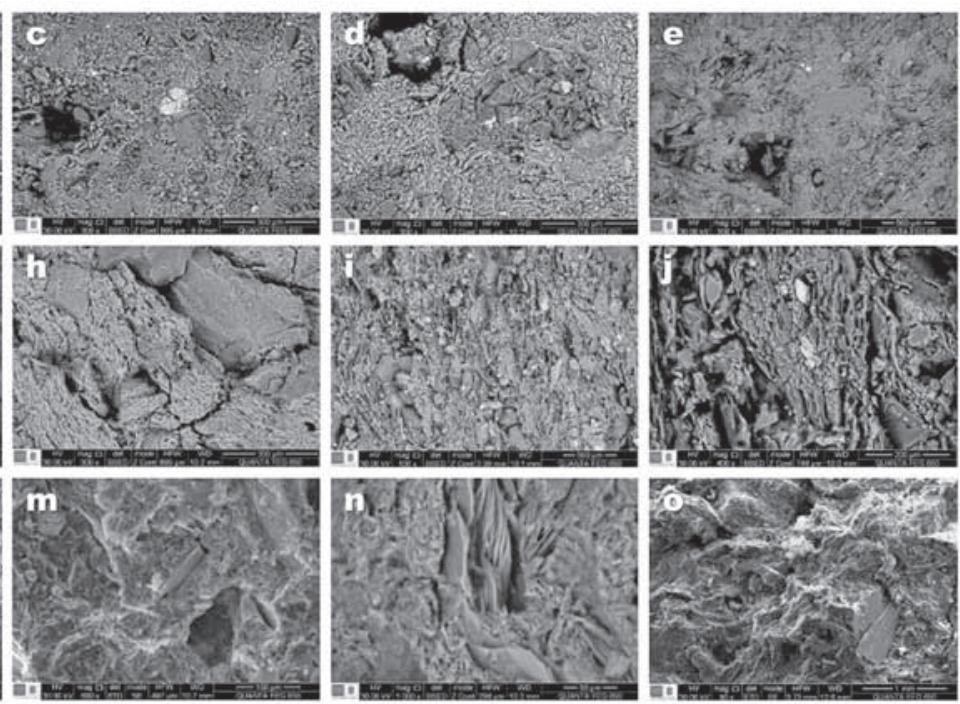

FIGURE 5. SEM photomicrographs of pottery samples of the (A)-(C) red, (D)-(F) gray, (G)-(I) black, (J)-(L) brown and (M)(O) reddish brown groups.

\section{Fourier transform infrared spectroscopy}

FIGURE 6 illustrates the FTIR-ATR spectra of the analized pottery sherds. According to the FTIR analysis of the archeological artifacts, there is not a great variation on mineralogy, which reveal that the analyzed pottery shreds can represent products manufactured from raw materials from a similar origin. The absorption bands at $3420-3431 \mathrm{~cm}^{-1}$ can be attributed to the $\mathrm{OH}$ stretching vibration of $\mathrm{H}_{2} \mathrm{O}$ adsorbed on the surface of pottery and the bending $\mathrm{H}-\mathrm{O}-\mathrm{H}$ vibration $(\delta)$ of water due to the exposure of the powders to atmosphere, respectively, as reported by Dubnikova et al. (2011). The absorption bands at $3420-3436 \mathrm{~cm}^{-1}$ (stretching vibration of $-\mathrm{OH}$ ) can be attributed to quartz or calcite. The weak absorption band at 1636-1649 $\mathrm{cm}^{-1}$ indicates $\mathrm{OH}$ bending modes of water or hydroxyls in the analyzed samples (Schrader, 1995). The peak at $1636 \mathrm{~cm}^{-1}$ corresponds to the bending vibration of $-\mathrm{OH}$ from $\mathrm{Si}-\mathrm{OH}$ silanol groups in quartz. The absorption bands at $1636-1649 \mathrm{~cm}^{-1}$ is attributed to the $\mathrm{H}-\mathrm{O}-\mathrm{H}$ bending of water molecule existing in muscovite-rich samples as suggested by Palanivel and Velraj (2007). The main $\mathrm{CO}_{3}$ band of the calcite in the pottery is located at $1420-1450 \mathrm{~cm}^{-1}$. The characteristic peaks ranging from 900 to $1200 \mathrm{~cm}^{-1}$ are attributed to the symmetrical stretching of Si-O bonds (e.g., Chaikina and Kryukova, 2004; Zhou et al., 2008) in quartz, albite and muscovite. The absence of a strong intensity peak at $1085 \mathrm{~cm}^{-1}$ in the spectra reveals that wollastonite is not present in the analyzed pottery shreds, which has been reported in previous studies (e.g., Dowty, 1987). The absorption bands at 793-797 $\mathrm{cm}^{-1}$ and $775-780 \mathrm{~cm}^{-1}$ are attributed to the bending vibrations of Si-O bonds (e.g., Chaikina and Kryukova, 2004; Zhou et al., 2008) and deformation of Si-O bonds respectively in quartz. The absorption band at $569 \mathrm{~cm}^{-1}$ can be attributed to the Fe-O vibration of magnetite (Velraj et al., 2009). However, hematite, which is characterized by absorption bands at 530-531 $\mathrm{cm}^{-1}$ also occur. According to Palanivel and RajeshKumar (2011), the formation of magnetite and hematite depend on the firing atmosphere prevalent at the time of manufacture. The presence of weak intensity peaks of hematite reveals the incipient transformation of magnetite $\left(\mathrm{Fe}_{3} \mathrm{O}_{4}\right)$ to hematite $\left(\mathrm{Fe}_{2} \mathrm{O}_{3}\right)$ during the firing process under an oxidizing condition (Velraj et al., 2009). The absorption bands at 464-469 $\mathrm{cm}^{-1}$ are assigned to the presence of quartz, albite and microcline. The Si-O bending mode of quartz appears at $465-470 \mathrm{~cm}^{-1}$. 


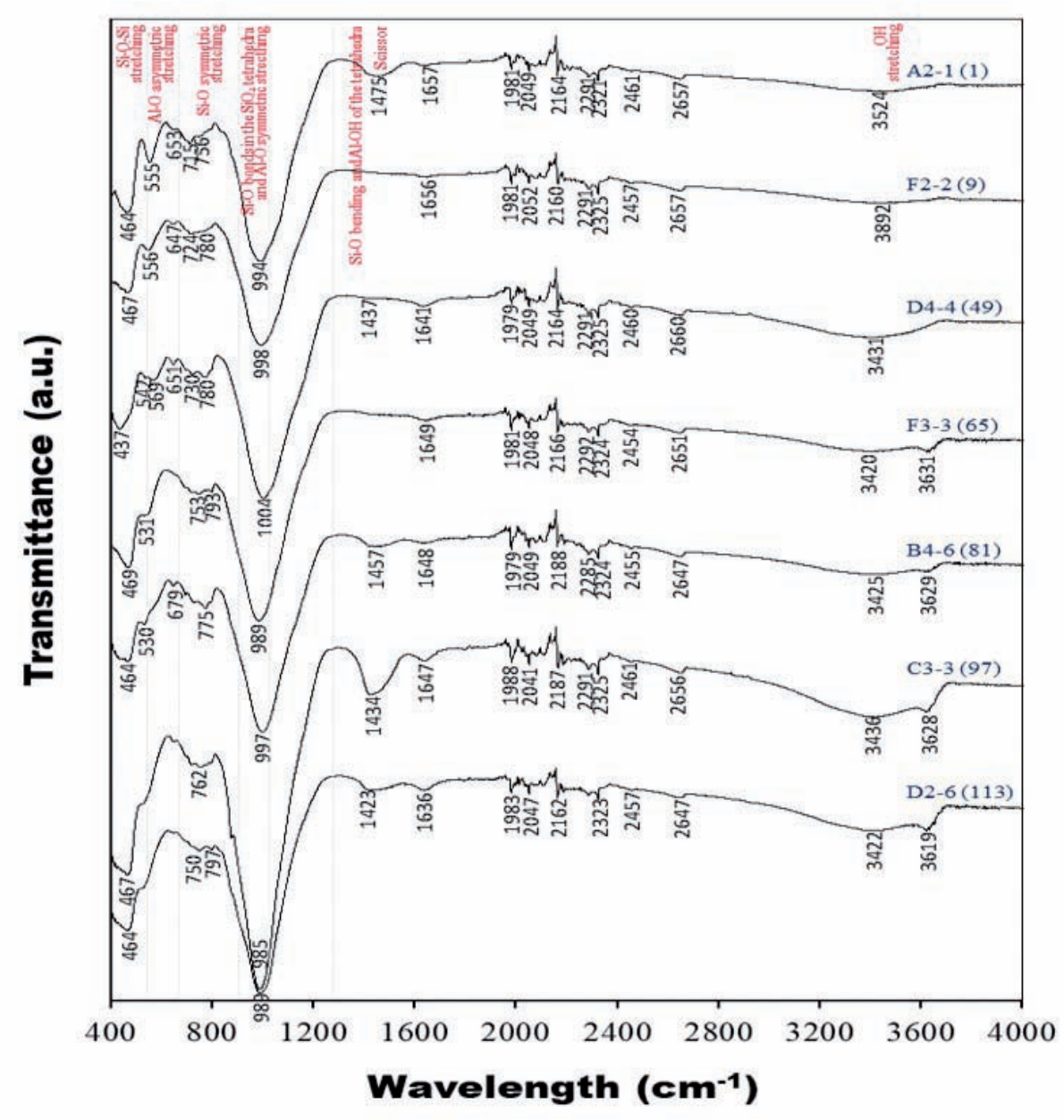

FIGURE 6. FTIR-ATR spectra of the analyzed pottery sherds.

The samples A2-1 (1) and F2-2 (9) from the red group (FIGURE 7A) show similar spectra, which indicates the presence of quartz $\left(695,794,1160 \mathrm{~cm}^{-1}\right)$, calcite (711, 835, 879 and $1456 \mathrm{~cm}^{-1}$ ), muscovite (1062 and $\left.553 \mathrm{~cm}^{-1}\right)$, muscovite/albite $\left(990 \mathrm{~cm}^{-1}\right)$, albite/microcline $\left(742 \mathrm{~cm}^{-1}\right)$ and albite $\left(649\right.$ and $\left.1032 \mathrm{~cm}^{-1}\right)$. Muscovite, microcline and albite are more clearly inferred using the second derivative. In the brown group, sample C3-3 (97) has higher absorbance rates than sample A3-4 (17) (FIGURE 7B). The vibration bands at 694, 798 and $1160 \mathrm{~cm}^{-1}$, and at 875 and $1420 \mathrm{~cm}^{-1}$, can be attributed to quartz and calcite, respectively. The second derivative reveals the presence of muscovite at $1022 \mathrm{~cm}^{-1}$, albite at 530 and $1096 \mathrm{~cm}^{-1}$, microcline at 463, 648, 768, 1049, 1134 and $1142 \mathrm{~cm}^{-1}$, wollastonite at 540, 640, 930, 1026, 1057 and $1088 \mathrm{~cm}^{-1}$, kaolinite at 938 and $1034 \mathrm{~cm}^{-1}$, illite at $1030 \mathrm{~cm}^{-1}$, diopside at $470,510,864$ and $965 \mathrm{~cm}^{-1}$, anorthite at 482, 540, 575 and $668 \mathrm{~cm}^{-1}$, and orthoclase at $428 \mathrm{~cm}^{-1}$. The highest absorption peak is $990 \mathrm{~cm}^{-1}$, which can be attributed to muscovite or albite. FIGURE 7C shows quite similar spectra for samples F3-3 (65) of the gray group and D2-6 (113) of the reddish brown group. However, the spectra present variations in the number of bands with presence of calcite, in F3-3 (65) (714, 877 and $\left.1420 \mathrm{~cm}^{-1}\right)$ and D2-6 (113) $\left(714 \mathrm{~cm}^{-1}\right)$. The spectra also show the presence of quartz $(695,777,797$ and $1160 \mathrm{~cm}^{-1}$ ), muscovite/albite (982 and $990 \mathrm{~cm}^{-1}$ ), albite (530 and $746 \mathrm{~cm}^{-1}$ ) and microcline $\left(650 \mathrm{~cm}^{-1}\right)$. On the other hand, the second derivative shows that the sample with the highest amount of calcite the bands are more pronounced and displays minor quartz bands and probably presents anorthite $\left(668 \mathrm{~cm}^{-1}\right)$. The red group (FIGURE 7D) shows more similar spectra to each other although with different indices of absorbance. The spectrum reveals the presence of quartz $(695,777$, 798 and $\left.1160 \mathrm{~cm}^{-1}\right)$, orthoclase/muscovite $\left(535 \mathrm{~cm}^{-1}\right)$, orthoclase $\left(580 \mathrm{~cm}^{-1}\right)$, albite $\left(530\right.$ and $\left.645 \mathrm{~cm}^{-1}\right)$, muscovite/albite $\left(725 \mathrm{~cm}^{-1}\right)$, muscovite $\left(1021 \mathrm{~cm}^{-1}\right)$ and 
kaolinite $\left(1000 \mathrm{~cm}^{-1}\right)$. Calcite at $1420 \mathrm{~cm}^{-1}$ was observed only in sample B4-6 (81). In the second derivative, microcline, wollastonite, sanidine, kaolinite, anortite and calcite were observed. A small amount of diopside with an absorption peak of $470 \mathrm{~cm}^{-1}$ was also observed. FIGURE 7E illustrates the spectrum of sample B2-2 (33) (red group), which indicates the presence of quartz (530, 695, 776, 795 and $\left.1160 \mathrm{~cm}^{-1}\right)$, albite $\left(1030 \mathrm{~cm}^{-1}\right)$ and microcline $\left(646 \mathrm{~cm}^{-1}\right)$. In the second derivative, muscovite at $1022 \mathrm{~cm}^{-1}$, kaolinite at $1010 \mathrm{~cm}^{-1}$, diopside
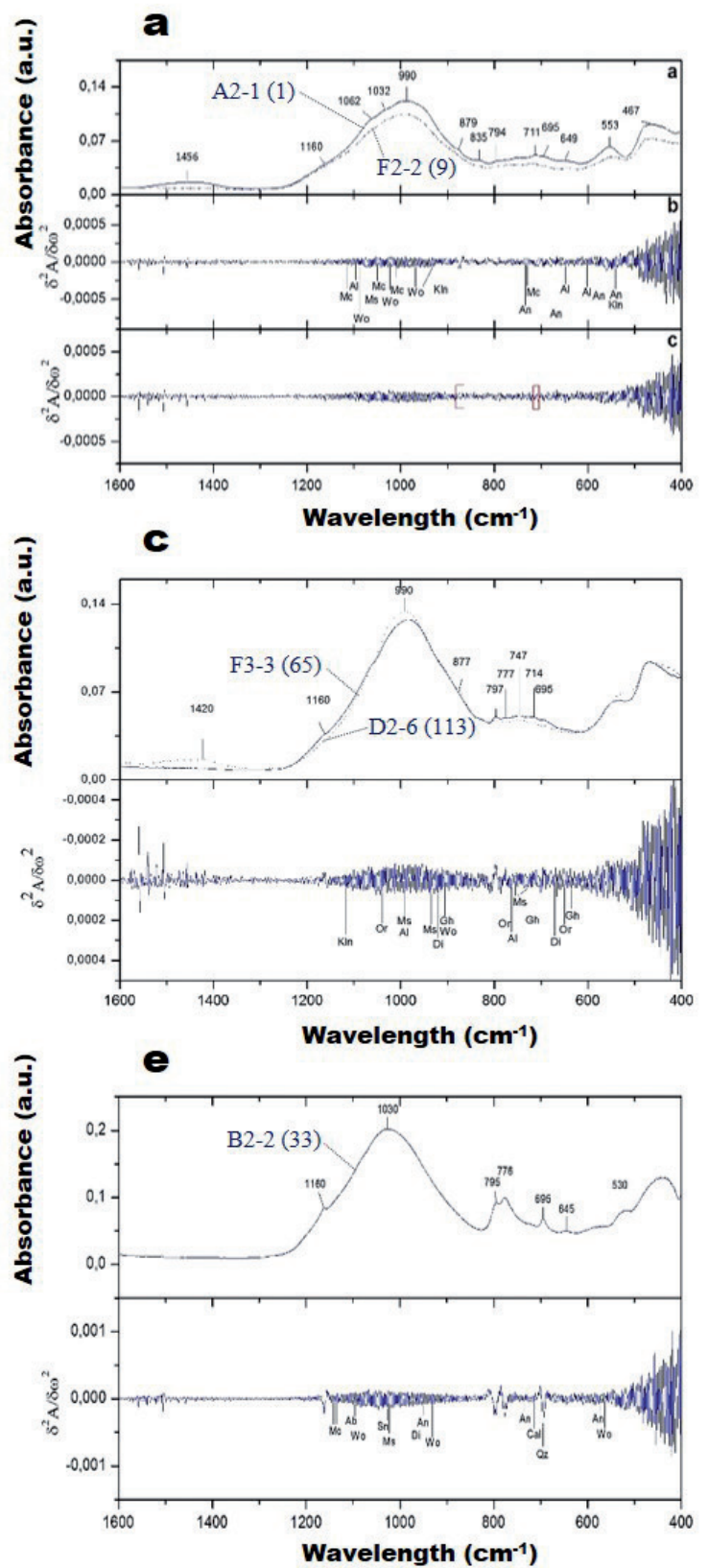

at $965 \mathrm{~cm}^{-1}$ and anorthite at 575, 733 and $950 \mathrm{~cm}^{-1}$, wollastonite (563, 930 and $1088 \mathrm{~cm}^{-1}$ ) and sanidine at $1026 \mathrm{~cm}^{-1}$ can be distinguished. FIGURE 7F illustrates the spectrum of sample A2-4 (89), which indicates the presence of quartz $\left(512,694,778,797\right.$ and $\left.1160 \mathrm{~cm}^{-1}\right)$, calcite (712, 874 and $\left.1420 \mathrm{~cm}^{-1}\right)$, and microcline/ orthoclase $\left(1010 \mathrm{~cm}^{-1}\right)$. It is also possible to identify in the second derivative minerals as albite, orthoclase, microcline, sanidine, anorthite, muscovite, wollastonite and kaolinite.
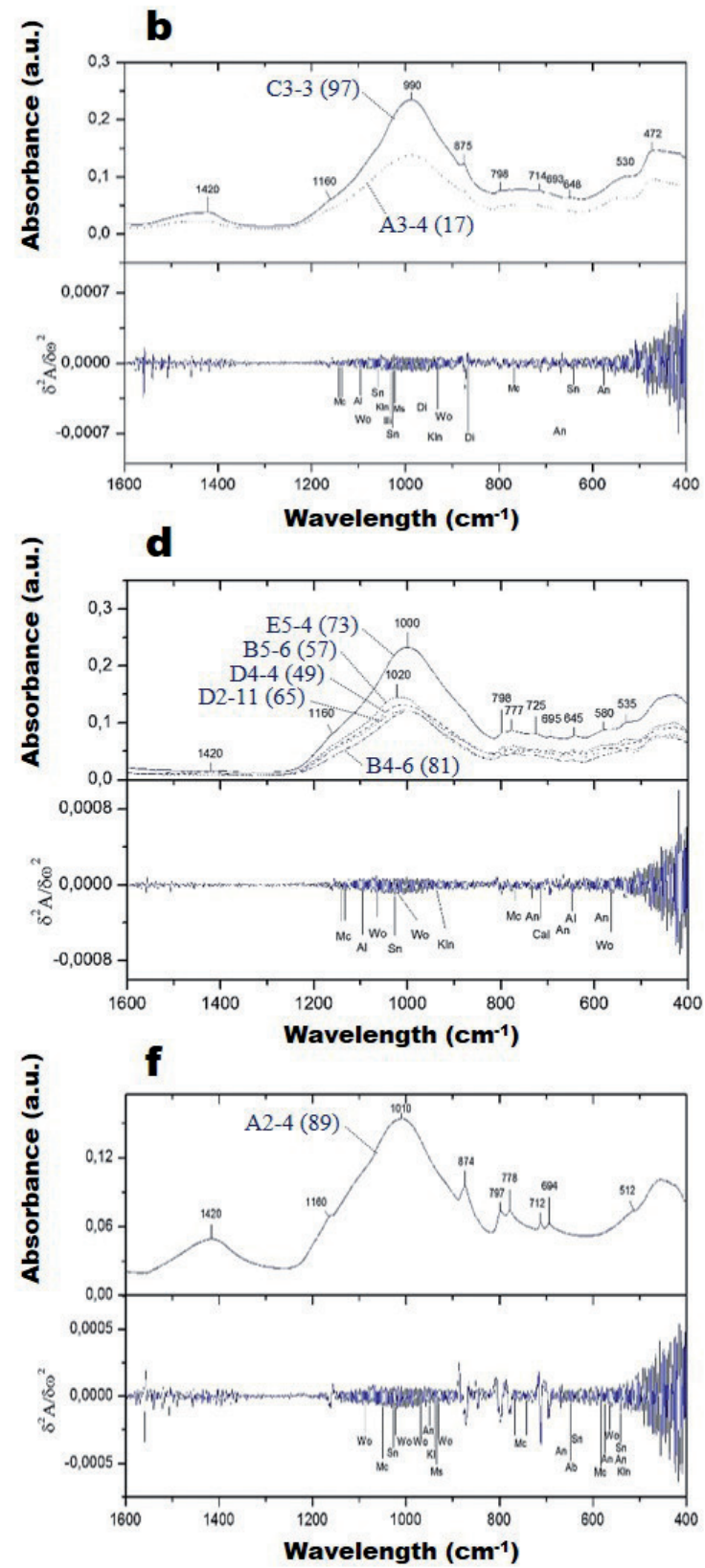

FIGURE 7. FTIR-ATR spectra and second derivative of the analyzed pottery sherds (spectra according to TABLE 1). 


\section{Estimation of the firing temperature conditions for the manufacture of potteries}

The raw material for manufacturing was undoubtedly clay, which consists of clay minerals (kaolinite) mixed with a variety of other minerals as quartz, muscovite, potassium feldspar and plagioclase. Quartz, potassium feldspar and plagioclase are stable even at high temperatures, so that they cannot be considered for the estimation of the firing temperature (e.g., İssi et al., 2011). According to Kakali et al. (2001), between $\sim 400-650^{\circ} \mathrm{C}$, the kaolinite dehydroxylation promotes its transformation to an amorphous phase (metakaolinite), which can occur in the temperature range of $450-650^{\circ} \mathrm{C}$ (e.g., Frost et al., 2003; Chakchouk et al., 2009). Noncalcareous clays show minor occurrence of magnetite and/or hematite. It is probably that clay minerals disappeared between $550^{\circ} \mathrm{C}-950^{\circ} \mathrm{C}$. Close to $950^{\circ} \mathrm{C}$, orthoclase and/or microcline can form at expenses of the progressive disappearance of plagioclase and muscovite, reaching its maximum abundance at $1100^{\circ} \mathrm{C}$. On the other hand, taking into account that muscovite disappears at $950-1000^{\circ} \mathrm{C}$ and plagioclase at $\sim 1100^{\circ} \mathrm{C}$, we suggest a maximum firing temperature of $950^{\circ} \mathrm{C}$. Carbonate-rich clays show variable amounts of calcite and small amounts of magnesium calcite, plagioclase and alkaline feldspar. Clay minerals were the first minerals to disappear at $950^{\circ} \mathrm{C}$. Carbonates can react with other components to produce mineral phases as gehlenite, diopside, and wollastonite (Trindade et al., 2009). At temperatures above $950^{\circ} \mathrm{C}$ in the presence of sufficient $\mathrm{SiO}_{2}$ and $\mathrm{CaO}$, gehlenite can react to anorthite and wollastonite. The presence of carbonates suggests firing temperatures lower than $700^{\circ} \mathrm{C}$. According to Grapes (2010), calcite reacts at $600-700^{\circ} \mathrm{C}$, which is unlikely taking into account that it still remains in some pottery sherds. Several studies (e.g., Holakooei et al., 2014; Velraj et al., 2015) reveal that the maximum temperature after which calcite occurs is $900^{\circ} \mathrm{C}$. However, the presence of magnesium calcite is indicative of temperatures slightly lower than those indicated by calcite, taking into account that it reacts in the range $500-650^{\circ} \mathrm{C}$ (Grapes, 2010). Alkaline feldspar disappeared at temperatures close to $950^{\circ} \mathrm{C}$ and plagioclase seemed to persist up to $1100^{\circ} \mathrm{C}$. Quartz is known for its low reactivity and inalterability despite high temperature changes. According to Liou (2015), anatase is a stable mineral phase, which can remain after firing of the raw materials, suggesting a firing temperature in the range of $750-950^{\circ} \mathrm{C}$. Firing conditions were variable, under oxidation and reduction environments, although the presence of magnetite possibly indicates predominantly reducing conditions.
With regard to the origin of the raw materials with which the pottery sherds object of this study were prepared, they probably came from the middle member of the Los Santos Formation, which is compossed of claystones, siltstones and muddy fine-grained sandstones of very local extension, developing a thin layer on top of the Mesa de Los Santos region. We consider that the local manufactured pottery is the same without changes in the time but only with variations on the surface colors, examining the possible regional provenance of the pottery sherds and elucidating broad questions regarding the raw clayed paste for manufacture choices and the sociocultural background of the pre-Hispanic cultures.

\section{CONCLUSIONS}

This study dealt with the characterization of fourteen pottery sherds from Los Teres archaeological site located in the region of the Mesa de Los Santos region, Colombia. The pottery sherds were studied by the archaeologist to define the ceramic system, based on two determining variables present in the sample: (1) the color of the bath or slip of the surface and (2) the mineralogical composition of the paste for each group. To correlate these two variables of archaeological analysis and determine if the communities added as a degreaser to the paste, substances or local or foreign minerals, XRPD, SEM and FTIR-ATR analyses were performed in order to extract information about mineralogy and firing temperatures as a contribution to elucidate a possible regional provenance. On the other hand, from the cultural point of view, the decoration color in slips does come to be a differentiating marker of the cultural group and the use of ceramics. There are not significant changes regard firing temperature conditions and mineralogy, which suggests that there were no significant transformations in the treatment of pasta and its incidence in the ceramic body. Results reported in this work contribute to developing and progressing in the archaeometry analysis of pottery sherds in Colombia, and in the advancing in the knowledge and understanding of ancient civilizations. The results reported in this paper also show that there is a management of local mineral resources, both to make lithic tools, and to grind them and use them in the paste as a degreaser for the manufacture of pottery. Likewise, they contribute to the development and progress in the analysis of the archeometry of ceramic pottery in northeastern Colombia and in the advance in the knowledge and understanding of the pre-Hispanic societies in this region. 


\section{ACKNOWLEDGEMENTS}

We gratefully acknowledge the Vicerrectoría de Investigación y Extensión of the Universidad Industrial de Santander for the use of their research facilities. Authors thank the Microscopy and X-Rays laboratories of the Guatiguará Technology Park and their staff for the analytical service provided for data acquisition. The authors would also like to acknowledge the anonymous referees for their critical and insightful reading of the manuscript and are most grateful to the above-named people and institutions for support.

\section{REFERENCES}

Barone, G., Lo Giudice, A., Mazzoleni, P., Pezzino, A., Barilaro, D., Crupi, V., and Triscari, M. (2005). Chemical characterization and statistical multivariate analysis of ancient pottery from Messina, Catania, Lentini and Sicarusa (Sicily). Archaeometry, 47(4), 745-762. doi: 10.1111/j.1475-4754.2005.00230.x.

Barrios-Neira, J., Montealegre, L., López, L.A., and Romero, L. (2009). Ceramics of Ategua (Córdoba, Spain): mineralogical and petrographic study. Applied Clay Science, 42(3-4), 529-537. doi: 10.1016/j.clay.2008.06.018.

Belfiore, C.M., Day, M.D., Hein, A., Kilikoglou, V., La Rosa, V., Mazzoleni, P., and Pezzion, A. (2007). Petrographic and chemical characterization of pottery production of the late Minoan I Kiln at Hagia triada, Crete. Archaeometry, 49(4), 621653. doi: 10.1111/j.1475-4754.2007.00324.x.

Belfiore, C.M., di Bella, M., Triscari, M., and Viccaro, M. (2010). Production technology and provenance study of archaeological ceramics from relevant sites in the Acantary River Valley (North-eastern Sicily). Materials Characterization, 61(4), 440451. doi: 10.1016/j.matchar.2010.01.012.

Bong, W.S.K., Matsumura, K., Yokoyama, K., and Nakai, I. (2010). Provenance study of early and middle bronze age pottery from KamanKalehöyük, Turkey, by heavy mineral analysis and geochemical analysis of individual hornblende grains. Journal of Archaeological Science, 37(9), 2165-2178. doi: 10.1016/j.jas.2010.03.013.

Chaikina, M.V., and Kryukova, G.N. (2004). Structural transformations in quartz and apatite on mechanical activation. Journal of Structural Chemistry, 45(Supplement 1), 121-126. doi: 10.1007/s10947-006-0106-1.

Chakchouk, A., Trifi, L., Samet, B., and Bouaziz, S. (2009). Formulation of blended cement: Effect of process variables on clay pozzolanic activity. Construction and Building Materials, 23(3), 13651373. doi: 10.1016/j.conbuildmat.2008.07.015.

Damjanović, L., Bikić, V., Šarić, K., Erić, S., and Holclajtner-Antunović, I. (2014). Characterization of the early Byzantine pottery from Caričin Grad (South Serbia) in terms of composition and firing temperature. Journal of Archaeological Science, 46, 156-172. doi: 10.1016/j.jas.2014.02.031.

Dowty, E. (1987). Vibrational interactions of tetrahedra in silicate glasses and crystals. Physics and Chemistry of Minerals, 14(1), 80-93. doi: 10.1007/BF00311151.

Dubnikova, N., Garskaite, E., Beganskiene, A., and Kareiva, A. (2011). Sol-gel synthesis and characterization of sub-microsized lanthanide (Ho, Tm, Yb, Lu) aluminium garnets. Optical Materials, 33(8), 1179-1184. doi: 10.1016/j. optmat.2011.02.008.

Frost, R.L., Horváth, E., Makóc, E., Kristóf, J., and Rédey, A. (2003). Slow transformation of mechanically dehydroxylated kaolinite to kaolinite - an aged mechanochemically activated formamide - intercalated kaolinite study. Thermochimica Acta, 408(1-2), 103-113. doi: 10.1016/S0040-6031(03)00316-2.

Grapes, R. (2010). Pyrometamorphism. 2nd edition, Heidelberg: Springer.

Grifa, C., De Bonis, A., Langella, A., Mercurio, M., Soricelli, G., and Morra, V. (2013). A Late Roman ceramic production from Pompeii. Journal of Archaeological Science, 40(2), 810-826. doi: 10.1016/j.jas.2012.08.043.

Holakooei, P., Tessari, U., Verde, M., and Vaccaro, C. (2014). A new look at XRD patterns of archaeological ceramic bodies: an assessment for the firing temperature of 17th century haft rang tiles from Iran. Journal of Thermal Analysis and Calorimetry, 118(1), 165-176. doi: 10.1007/ s10973-014-4012-z. 
Iordanidis, A., Garcia-Guinea, J., and KaramitrouMentessidi, G. (2009). Analytical study of ancient pottery from the archaeological site of Ariani, northern Greece. Materials Characterization, 60(4), 292-302. doi: 10.1016/j. matchar.2008.08.001.

İssi, A., Kara, A., and Alp, A.O. (2011). An investigation of Hellenistic period pottery production technology from Harabezikan/Turkey. Ceramics International, 37(7), 2575-2582. doi: 10.1016/j. ceramint.2011.04.001.

Kahl, W.A., and Ramminger, B. (2012). Nondestructive fabric analysis of prehistoric pottery using high-resolution X-ray microtomography: a pilot study on the late Mesolithic to Neolithic site Hamburg-Boberg. Journal of Archaeological Science, 39(7), 2206-2219. doi: 10.1016/j. jas.2012.02.029.

Kakali, G., Perraki, T., Tsivilis, S., and Badogiannis, E. (2001). Thermal treatment of kaolin: the effect of mineralogy on the pozzolanic activity. Applied Clay Science, 20(1-2), 73-80. doi: 10.1016/ S0169-1317(01)00040-0.

Kramar, S., Lux, J., Mladenović, A., Pristacz, H., Mirtič, B., Sagadin, M., and Rogan-Šmuc, N. (2012). Mineralogical and geochemical characteristics of Roman pottery from an archaeological site near Mošnje (Slovenia). Applied Clay Science, 57, 3948. doi: 10.1016/j.clay.2011.12.008.

Lettieri, M. (2015). Infrared spectroscopic characterization of residues on archaeological pottery through different spectra acquisition modes. Vibrational Spectroscopy, 76, 48-54. doi: 10.1016/j.vibspec.2014.12.002.

Liou, Y.(2015). Multi-technique study of archaeological cord-marked wares decorated with red coatings from Taiwan. Journal of Raman Spectroscopy, 46(1), 133-140. doi: 10.1002/jrs.4621.

Mangone, A., Giannossa, L.C., Laviano, R., Fiorello, C.S., and Traini, A. (2009). Investigation by various analytical techniques to the correct classification of archaeological finds and delineation of technological features. Late Roman lamps from Egnatia. From imports to local production. Microchemical Journal, 91(2), 214221. doi: 10.1016/j.microc.2008.11.006.

Maniatis, Y., and Tite, M. (1978). Ceramic technology in the Aegean world during the Bronze Age. In: C. Doumas (ed.). Thera and the Aegean world (pp. 482-492). Vol. 1, London.

Maniatis, Y., and Tite, M. (1981). Technological examination of Neolithic-Bronze Age pottery from central and southeast Europe and from the Near East. Journal of Archaeological Science, 8(1), 59-76. doi: 10.1016/0305-4403(81)90012-1.

Moreno-González, L. (2012). Una aproximación a la sociología religiosa de la cultura prehispánica Guane: muerte y prácticas funerarias. Anuario de Historia Regional y de las Fronteras, 17(1), 1325.

Moroni, B., and Conti, C. (2006). Technological features of Renaissance pottery from Deruta (Umbria, Italy): an experimental study. Applied Clay Science, 33(3-4), 230-246. doi: 10.1016/j. clay.2006.05.002.

Noll, W., and Heimann, R.B. (2016). Ancient old world pottery: Materials, technology, and decoration. Stuttgart: Schweizerbart Science Publishers.

Palanivel, R., and Velraj, G. (2007). FTIR and FTRaman spectroscopic studies of fired clay artifacts recently excavated in Tamilnadu, India. Indian Journal of Pure \& Applied Physics, 45, 501-508.

Palanivel, R., and Rajesh-Kumar, U. (2011). The mineralogical and fabric analysis of ancient pottery artifacts. Cerâmica, 57(341), 56-62.

Ravisankar, R., Naseerutheen, A., Raja-Annamalai, G., Chandrasekaran, A., Rajalakshmi, A., Kanagasabapathy, K.V., Prasad, M.V.R., and Satpathy, K.K. (2014). The analytical investigations of ancient pottery from Kaveripakkam, Vellore dist, Tamilnadu by spectroscopic techniques. Spectrochimica Acta Part A: Molecular and Biomolecular Spectroscopy, 121, 457-463. doi: 10.1016/j. saa.2013.10.110. 
Schrader, B. (1995). Infrared and Raman Spectroscopy: Methods and applications. Weinheim: VCH.

Schwedt, A., and Mommsen, H. (2004). Clay paste mixtures identified by neutron activation analyses in pottery of a Roman workshop in Bonn, Germany. Journal of Archaeological Science, 31(9), 1251-1258. doi: 10.1016/j.jas.2004.02.003.

Sciau, P. (2016). Nano-crystallization in decorative layers of Greek and Roman ceramics. In: P. Dillmann, L. Bellot-Gurlet, I. Nenner (eds.). Nanoscience and Cultural Heritage (pp. 41-58). Paris: Atlantis Press. doi: 10.2991/978-94-6239198-7_2.

Sherriff, B.L., Court, P., Johnston, S., and Striling, L. (2002). The source of raw materials for Roman pottery from Leptiminus, Tunisia. Geoarchaeology: An International Journal, 17(8), 835-861. doi: 10.1002/gea.10043.

Tarquini, G., Nunziante-Cesaro, S., and Campanella, L. (2014). Identification of oil residues in Roman amphorae (Monte Testaccio, Rome): a comparative FTIR spectroscopic study of archeological and artificially aged samples. Talanta, 118, 195-200. doi: 10.1016/j.talanta.2013.09.060.

Tite, M.S., Freestone, I.C., Meeks, N.D., and Bimson, M. (1982). The use of scanning electron microscopy in the technological examination of ancient ceramics. In: A.D. Franklin, J. Olin (eds.). Ceramics as Archaeological Material (pp. 109120). Washington: Smithsonian Institution Press.

Trindade, M.J., Dias, M.I., Coroado, J., and Rocha, F. (2009). Mineralogical transformations of calcareous rich clays with firing: A comparative study between calcite and dolomite rich clays from Algarve, Portugal. Applied Clay Science, 42(3-4), 345-355. doi: 10.1016/j.clay.2008.02.008.

Velraj, G., Janaki, K., Mohamed-Musthafa, A., and Palanivel, R. (2009). Spectroscopic and porosimetry studies to estimate the firing temperature of some archaeological pottery shreds from India. Applied Clay Science, 43(3-4), 303-307. doi: 10.1016/j.clay.2008.09.005.

Velraj, G., Tamilarasu, S., and Ramya, R. (2015). FTIR, XRD and SEM-EDS studies of archaeological pottery samples from recently excavated site in Tamil Nadu, India. Materials Today: Proceedings, 2(3), 934-942. doi: 10.1016/j.matpr.2015.06.012.

Whitney, D.L., and Evans, B.W. (2010). Abbreviations for names of rock-forming minerals. American Mineralogist, 95(1), 185-187. doi: 10.2138/ am.2010.3371.

Zhou, Y.S., He, C.R., and Yang, X.S. (2008). Water contents and deformation mechanism in ductile shear zone of middle crust along the Red River fault in southwestern China. Science in China Series D: Earth Sciences, 51(10), 1411-1425. doi: 10.1007/s11430-008-0115-3.

Karina Andrea Portilla-Mendoza

ORCID: 0000-0002-4709-8098

Diego Armando Pinzón-Núñez

ORCID: 0000-0001-7258-5173

Leonardo Moreno-González

ORCID: 0000-0002-8979-4710

Ricardo Mier-Umaña

ORCID: 0000-0001-8769-8680

Carlos Alberto Ríos Reyes

ORCID: 0000-0002-3508-0771

Jose Antonio Henao-Martínez

ORCID: 0000-0002-5097-5661

Trabajo recibido: agosto 26 de 2018

Trabajo aceptado: abril 09 de 2019 